\title{
Existing Dairy Husbandry Practices followed by Livestock owners in Farrukhabad District of Uttar Pradesh, India
}

\author{
Avanish Kumar, Vipin Kumar Upadhyay* and Vishwa Pratap Singh \\ Animal Husbandry and Dairying Department, Raja Balwant Singh College, \\ Agra, U.P.283105, India \\ *Corresponding author
}

\section{A B S T R A C T}

\section{Keywords}

Dairy animals, Housing, Feeding, Milking, Health, Management

Article Info

\section{Accepted:}

08January 2020 Available Online: 10 February 2020
A study was carried out to collect the information regarding existing dairy husbandry practices along with health management practices from 180 selected respondents with the help of predesigned questionnaire in Farrukhabad district of Uttar Pradesh. The present Study revealed that majority of respondents $(80.6 \%)$ kept their animal inside dwelling house in thatched roof shed $(62.8 \%)$ with kuccha floor $(80.6 \%)$ and cemented manger $(86.7 \%)$. It was observed that $66.7 \%$ respondents practice both stall feeding along with grazing and provide home grown as well as purchased feed and fodder and only few respondents (17.8\%) provide the extra feed during pregnancy and milking of the animals. It was observed that most of the respondents $(73.3 \%)$ detect heat by mucus discharge as well as bellowing of animal and follow the artificial insemination within 12-18 hr after the detection of heat. Only $28.9 \%$ respondents follow the deworming schedule of calf and adult animals while almost all the respondent follow the vaccination of animals. Finally on the basis of result findings it is concluded that most of the respondents follow the traditional husbandry practices for their livelihood because they do not have the knowledge of modern dairy husbandry practices.

\section{Introduction}

Dairy husbandry plays an important role in the national economy by providing employment and nutrients to the millions of people residing in rural and urban area of the country.India continues to be the largest producer of milk in the world. Total milk production during 2016-17 was 165.4 million tones. The per capita availability of milk was around 355 grams per day in 2016-17 (Anon 2017). Therefore, dairy development in India has been an effective and important instrument of rural development as it generates self-employment opportunities.

Production potential of livestock depends to a much extent on the management practices 
which vary significantly within agroecological regions. Hence, understanding husbandry management practices of the region is necessary to identify the strengths and weaknesses of the rearing systems and to formulate suitable intervention policies (Gupta et al., 2008). Each component of management practices i.e. breeding, housing, feeding and healthcare interacts either directly or indirectly to affect the productivity of the livestock. Considering these facts, the present study was designed to investigate the existing dairy husbandry practices adopted by livestock owners in Farrukhabad district of Uttar Pradesh.

\section{Materials and Methods}

A cross section survey was carried out in selected areas of Farrukhabad district of Utter Pradesh during the year 2018-19 to collect the information from livestock owners regarding existing husbandry practices followed by the dairy farmers. The Farrukhabad district consists of three tahsils (Farrukhabad, Kaimganj and Amritpur). Twelve villages were selected randomly from each tahsiland from each selected village five progressive farmers having dairy animals were chosen as respondent.

A total 180 respondents were selected for the study. While selecting respondents due care was taken to ensure that they were evenly distributed in the village and was a true representative of animal management practices prevailing in the area. The selected respondents were interviewed personally and information was collected with the help of predesigned questionnaire. The data regarding dairy husbandry practices like housing, feeding, breeding, milking and health management practices of dairy animals were collected. The Data collected were classified, tabulated and analysed statistically using frequency and percentage.

\section{Results and Discussion}

\section{Housing management practices}

The data on the housing pattern adopted by the farmers has been shown in table 1.The present Study revealed that majority of respondents $(80.6 \%)$ had animal shed located inside dwelling house while only $19.4 \%$ had separate animal shed outside their house. Present finding is supported by Pata et al., (2018b) and contrary to Pundir et al., (2000).The perusal of the data revealed that the majority of the respondents kept their animals in thatched roof shed (62.8\%)followed by Asbestos sheet (25.0\%) and pucca sheds (12.2\%). These results are supported by Singh et al., (2015).Majority of respondents $(80.6 \%)$ had kuccha floor pattern followed by $19.4 \%$ pucca floor pattern (15.6\% brick edge and $3.9 \%$ cemented floor).

These findings are supported by Kalyankar et al., (2008) who found that the kuccha flooring was most common (91.56 per cent) in animal houses. Present findings were also supported by Sabapara et al., (2010) and Pata et al., (2018b) those also reported kuccha flooring to be most common type of flooring in their study area. From the results it is evident that all the respondents provided manger to their animals in which $86.7 \%$ were of pucca type i.e. cemented while $13.3 \%$ were made of local materials like mud, plastic etc. Contrary to this, Kalyankar et al., (2008) reported that 75 per cent farmers provided kuchcha type of stall in agro-climatic zone of Maharashtra state. Sinha et al., (2009) reported that the majority of feeding manger were kuchcha in rural areas, whereas, majority of farmers in semi urban and urban areas had pucca manger. In the present study it was found that majority of the farmers, who have smaller herd size, provided the adequate floor space to their animal to perform their natural behaviour while those have larger herd size 
were unable to provide adequate floor space. The findings are in agreement with the reports of Sinha et al., (2009) who found that 74.4 per cent of respondents in the rural and 86.7 per cent in urban area of Bareilly district of Uttar Pradesh had adequate floor space in their animal houses. Regarding cleanliness of the shed it was observed that majority of the respondents $(81.1 \%)$ have the satisfactory cleanliness in the animal shed while $18.9 \%$ respondents have non-satisfactory cleanliness.

It was observed that $84.4 \%$ respondents had provision of good ventilation for their animal shed. Findings of the present study are corroborated by the earlier studies conducted in Prabhani district of Maharashtra (Pawar et al., 2006; Bainwad et al., 2007) and Bareilly district of Uttar Pradesh (Sinha et al., 2009).It was found that majority of the respondents $(86.7 \%)$ dispose the manure from animal shed to manure pit while some respondents $(13.3 \%)$ dispose directly to the field. Sinhaet al., (2009) also reported that majority of respondents had manure pits.

\section{Feeding management practices}

Feeding is one of the most important aspects of husbandry practices. For optimum milk production, balanced and adequate feeding is important. The data on the feeding patterns adopted by the farmers of the Farrukhabad district of Uttar Pradesh has been shown in table 2. From the present investigation it was observed that $66.7 \%$ respondents practiced both stall and grazing followed by stall feeding (25.0\%) and grazing (8.3\%) alone. These findings are supported by Pata et al., (2018b) and Manohar et al., (2014) who reported that majority of the farmers followed both grazing as well as stall feeding system. It was revealed from the present study that majority of the farmer $(82.2 \%)$ provide green fodder to their animals while $17.8 \%$ farmer were unable to fed green fodder to their animals and they provide only dry fodder along with concentrates. It was found that all the respondents provide the concentrate feed regularly $(63.9 \%)$ and occasionally $(36.1 \%)$ to their animals in the form of kitchen waste and concentrate feed available in the home or purchased from market. Majority of the respondents $(66.7 \%)$ used both home grown as well as purchased feed and fodder to feed their animals followed by home grown $(25 \%)$ and purchased $(8.3 \%)$. It was also observed that most of the farmer $(86.7 \%)$ did not provide mineral mixture to their animals These results are supported by Jadhavet al., (2014); Jatoliya et al., (2017) and Pata et al., (2018b) who studied that majority of the farmers did not provide mineral mixture to their animals. Almost all the farmers have the provision of clean drinking water facility for their animals. In the present investigation it was observed that only few respondents $(17.8 \%)$ provide the extra feed during pregnancy and milking of the animals.

\section{Reproductive management practices}

The results of various reproductive management practices followed by dairy farmer in the study area are presented in Table 3.It was observed that all respondents $(100 \%)$ relied on behavioural signs for the detection of heat in their dairy animals. Out of these $73.3 \%$ respondents detect heat by both mucus discharge and bellowing of animal followed by only mucus discharge (13.9\%), bellowing $(8.3 \%)$ and by mounting (4.4\%).Patel et al., (2005) also found that $76 \%$ farmers followed mucus discharge and bellowing as the symptoms of estrus in dairy animals.Chowdhry et al., (2006) conducted a study in Banaskantha district of North Gujarat and found that 28 percent farmers observed only mucus discharge as sole symptom of heat detection while 72 percent observed mucus discharge and bellowing as heat symptoms.Modi and Patel (2010) studied on 
breeding practices in dairy animals of rural area under milk shed of North Gujarat and reported that almost all farmers observed only mucus discharge and bellowing for heat detection.

It was found that majority of the farmer follow the artificial insemination for the breeding of dairy animals in which $75.6 \%$ respondent allow the insemination within 12 $18 \mathrm{hr}$ after the detection of heat while $24.4 \%$ follow after $18 \mathrm{hr}$ of heat detection. Chowdhry et al., (2006) observed that 98.61 percent and 1.39 percent farmers practiced A.I. and natural service, respectively for their crossbred cows.Modi and Patel (2010) studied the breeding practices in dairy animals of rural area under milk shed of North Gujarat and also reported that almost all farmers used AI. Malsawmdawngliana and Rahman (2016) found that the Artificial Insemination (AI) was within the reach of majority of the dairy farmers. Majority of the respondents (98.00\%) did AI within 12-18 hours after heat detection. AI was preferred by the farmers over natural service.

Majority of the respondents follow breeding of female after 3 months of calving and they did not follow the pregnancy diagnosis of dairy animals. This present finding is contrary to the finding of Singh et al., (2013) as reported that majority $(93.33 \%)$ of dairy farmers had highest adoption about AI in the animals at proper time of heat followed by heat detection in animals and service the cow within 60- 90 days after calving.

\section{Milking management practices}

The results of various milking management practices followed by dairy farmers in the study area are presented in Table 4 . In the present study all the farmers allowed their calves to suckle their dams for letdown of milk. They also allow the calf to suckle before and after the milking to feed the calf.

This study revealed that all the farmers were followed the practice of washing of teat and udder before milking. Similar findings were reported by Kushwaha et al., (2007), Chowdhry et al., (2008), Kalyankar et al., (2008), Sabapara (2015) who found that the majority of farmers followed hygienic steps before milking. The present findings are also supported by Pata et al., (2018a) and Sreedhar et al., (2017) who reported that majority of the respondents follow the practice of washing of teat and udder before milking. Majority of respondents $(60.0 \%)$ milked dairy animals by knuckling method followed by $27.8 \%$ respondents milked by full hand followed by $12.2 \%$ respondents milked by stripping method.

Present findings are supported by Pata et al., (2018) and Sreedhar et al., (2017) who indicated that majority of farmers followed knuckling method of milking.It was observed that $83.3 \%$ respondents practiced stripping at end of milking followed by $16.7 \%$ respondents did not practice stripping. These results are supported by Pata et al., (2018a) and Swaroop and Prasad (2009) who observed that $95.33 \%$ and $73 \%$ of the respondents followed stripping at the end of milking, respectively.

It was observed that all the respondents followed twice a day milking. These finding are supported Bashir et al., (2013); Pata et al., (2018a) and Tiwari et al., (2018) concluded that majority of the farmers practiced milking twice a day in their animals.

About $60 \%$ respondents were followed regular interval of milking in their animals while $40 \%$ were unable to follow regular milking interval. Similar findings were also reported by Malik and Nagpaul (1999). 
Table.1 Housing management practices

\begin{tabular}{|c|c|c|}
\hline \multicolumn{3}{|c|}{ Housing management practices } \\
\hline Category & No & Per Cent \\
\hline \multicolumn{3}{|l|}{ Location of shed } \\
\hline Inside dwelling house & 145 & 80.6 \\
\hline Separate from dwelling house & 35 & 19.4 \\
\hline \multicolumn{3}{|l|}{ Type of shed } \\
\hline Pucca & 22 & 12.2 \\
\hline Asbestos & 45 & 25.0 \\
\hline Thatch & 113 & 62.8 \\
\hline \multicolumn{3}{|l|}{ Type of floor } \\
\hline Kachcha & 145 & 80.6 \\
\hline Brick & 28 & 15.6 \\
\hline Cement & 7 & 3.9 \\
\hline \multicolumn{3}{|l|}{ Manger made of } \\
\hline Cement & 156 & 86.7 \\
\hline local material & 24 & 13.3 \\
\hline \multicolumn{3}{|l|}{ Floor space } \\
\hline Adequate & 128 & 71.1 \\
\hline Not adequate & 52 & 28.9 \\
\hline \multicolumn{3}{|l|}{ Cleanliness in the shed } \\
\hline Satisfactory & 146 & 81.1 \\
\hline Non - satisfactory & 34 & 18.9 \\
\hline \multicolumn{3}{|l|}{ Ventilation } \\
\hline Adequate & 152 & 84.4 \\
\hline Not adequate & 28 & 15.6 \\
\hline \multicolumn{3}{|l|}{ Drainage system } \\
\hline Good & 142 & 78.9 \\
\hline Poor & 38 & 21.1 \\
\hline \multicolumn{3}{|l|}{ Manure Disposal } \\
\hline Manure pit & 156 & 86.7 \\
\hline Direct to field & 24 & 13.3 \\
\hline
\end{tabular}

About $56.7 \%$ respondents reported that the total milk production was upto 5 litre/day followed by $6-10$ litre/day (31.1\%) and only $12.2 \%$ respondents have more than 10 litre/day production of milk

.It was found that majority of the respondents use some amount of milk for family consumption and rest of the milk they used to dispose through local vendors $(65.6 \%$ respondents) followed by middle man $(19.4 \%$ respondents) and co-operative society $(15.0 \%$ respondents). Majority of the respondents $(68.3 \%)$ were disposedtheir milk on quantity basis while others $(31.7 \%$ ) on quality (fat \%) basis. 
Table.2 Feeding management practices

\begin{tabular}{|c|c|c|}
\hline \multicolumn{3}{|c|}{ Feeding management practices } \\
\hline Category & No & Per Cent \\
\hline \multicolumn{3}{|l|}{ Feeding system } \\
\hline Stall feeding & 45 & 25.0 \\
\hline Only grazing & 15 & 8.3 \\
\hline Both (Stall + grazing) & 120 & 66.7 \\
\hline \multicolumn{3}{|l|}{ Source of feed fodder } \\
\hline Home grown & 45 & 25.0 \\
\hline Purchase & 15 & 8.3 \\
\hline Both home grown \& purchase & 120 & 66.7 \\
\hline \multicolumn{3}{|l|}{ Green fodder provide } \\
\hline Yes & 148 & 82.2 \\
\hline No & 32 & 17.8 \\
\hline \multicolumn{3}{|l|}{ Concentrate feeding } \\
\hline Regular & 115 & 63.9 \\
\hline Occasionally & 65 & 36.1 \\
\hline \multicolumn{3}{|l|}{$\begin{array}{l}\text { Feeding of salt and mineral } \\
\text { mixture }\end{array}$} \\
\hline Yes & 24 & 13.3 \\
\hline No & 156 & 86.7 \\
\hline \multicolumn{3}{|l|}{ Clean drinking water access } \\
\hline Yes & 180 & 100.0 \\
\hline No & 0 & 0.0 \\
\hline \multicolumn{3}{|c|}{ Extra allowance during pregnancy and milking } \\
\hline Yes & 32 & 17.8 \\
\hline No & 148 & 82.2 \\
\hline
\end{tabular}


Table.3 Reproductive management practices

\begin{tabular}{|l|c|c|}
\hline \multicolumn{2}{|c|}{ Breeding management practices } \\
\hline \multicolumn{1}{|c|}{ Category } & No & Per Cent \\
\hline Method of heat detection & 180 & 100.0 \\
\hline Symptom & 0 & 0.0 \\
\hline Teaser & & \\
\hline Symptoms of heat detection & 25 & 13.9 \\
\hline Mucus discharge & 15 & 8.3 \\
\hline Bellowing & 132 & 73.3 \\
\hline Mucus discharge + bellowing & 8 & 4.4 \\
\hline Mounting & & \\
\hline Breeding of females & 180 & 100.0 \\
\hline AI & 0 & 0.0 \\
\hline Natural service & 64 & 35.6 \\
\hline Insemination after heat detection & & 64.4 \\
\hline Within 12-18 hrs & 136 & 75.6 \\
\hline After 18 hrs & 44 & 24.4 \\
\hline Breeding after calving & & \\
\hline 2-3 months & & \\
\hline 3 months and after & & \\
\hline Pregnancy diagnosis & & \\
\hline Follow & & \\
\hline Not follow & & \\
\hline
\end{tabular}


Table.4 Milking management practices

\begin{tabular}{|c|c|c|}
\hline \multicolumn{3}{|c|}{ Milking management practices } \\
\hline Category & No & Per Cent \\
\hline \multicolumn{3}{|l|}{ Milking method } \\
\hline Full hand & 50 & 27.8 \\
\hline Stripping & 22 & 12.2 \\
\hline Knuckling & 108 & 60.0 \\
\hline \multicolumn{3}{|c|}{ Stripping at the end of milking } \\
\hline Yes & 150 & 83.3 \\
\hline No & 30 & 16.7 \\
\hline \multicolumn{3}{|l|}{ Let down of milk } \\
\hline Use calf & 180 & 100 \\
\hline Other & 00 & 00 \\
\hline \multicolumn{3}{|l|}{ Frequency of milking } \\
\hline Once a day & 0 & 0.0 \\
\hline Twice a day & 180 & 100.0 \\
\hline Thrice a day & 0 & 0.0 \\
\hline \multicolumn{3}{|l|}{ Milking interval } \\
\hline Regular & 108 & 60.0 \\
\hline Irregular & 72 & 40.0 \\
\hline \multicolumn{3}{|c|}{ Washing of teat and udder before milking } \\
\hline Yes & 180 & 100.0 \\
\hline No & 0 & 0.0 \\
\hline \multicolumn{3}{|c|}{ Total Milk production (liters/day) } \\
\hline upto 5 liters & 102 & 56.7 \\
\hline 6 to 10 liters & 56 & 31.1 \\
\hline$>10$ liters & 22 & 12.2 \\
\hline \multicolumn{3}{|c|}{ Disposal of milk after family consumption } \\
\hline Middle man & 35 & 19.4 \\
\hline Local vendor & 118 & 65.6 \\
\hline Co-operative society & 27 & 15.0 \\
\hline \multicolumn{3}{|c|}{ Sale of milk on the basis of } \\
\hline Fat $\%$ & 57 & 31.7 \\
\hline Quantity & 123 & 68.3 \\
\hline
\end{tabular}


Table.5 Health management practices

\begin{tabular}{|c|c|c|}
\hline \multicolumn{3}{|c|}{ Health management practices } \\
\hline Category & No & Per Cent \\
\hline \multicolumn{3}{|l|}{ Use of disinfectant } \\
\hline Yes & 45 & 25.0 \\
\hline No & 135 & 75.0 \\
\hline \multicolumn{3}{|c|}{ Deworming of animals } \\
\hline Follow & 52 & 28.9 \\
\hline Not follow & 128 & 71.1 \\
\hline \multicolumn{3}{|c|}{ Vaccination of animals } \\
\hline Yes & 180 & 100.0 \\
\hline No & 0 & 0.0 \\
\hline \multicolumn{3}{|c|}{ Treatment of animals by } \\
\hline Veterinary doctor & 102 & 56.7 \\
\hline Quack & 62 & 34.4 \\
\hline Follow ITK & 16 & 8.9 \\
\hline
\end{tabular}

\section{Health management practices}

The results of various health management practices followed by livestock owners in the study area are presented in Table 5.Majority $(75 \%)$ of the respondents did not use the disinfectant in the animal shed. This could be on account of their lack of awareness about importance of cleanliness of the shed. The results are in line with the findings of Singh $e t$ al., (2015); Meena et al., (2008) and Singh et al., (2007).

Only $28.9 \%$ respondents follow the deworming schedule of calf and adult animals and regarding vaccination almost all the respondent follow the vaccination of animals. For the treatment of diseased animals most of the respondents $(56.7 \%)$ follow the treatment by veterinary doctors, $34.4 \%$ by quack and 8.9\% respondents practice the indigenous technical knowledge for the treatment of animals. Finally on the basis of result findings of present investigation, it is concluded that most of the respondents are following the traditional husbandry practices because they do not have the knowledge of modern dairy husbandry practices. Therefore, these findings suggest that there is a need to organize awareness camps and training programmes regarding scientific dairy husbandry as well as health management practices.

\section{References}

Anonymous. 2017. Bulletin of Animal Husbandry and Dairying Statistics, Directorate of Animal Husbandry.

Bainwad, D. V.; Deshmukh, B. R.; Thombre, B M and Chauhan D S. 2007.Feeding and management practices adopted by buffalo farmers under watershed area. Indian Journal of Animal Research, 41(1): 68-70.

Bashir B P and Kumar V G. 2013. Milking management practices followed in selected areas of the Kottayam district of Kerala state. Journal of Life Science, 5(1): 53-55.

Chowdhry N R, Patel J B and Bhakat M. 2006.An overview of feeding, breeding 
and housing practices of dairy animals under milk co- operative system in Banaskantha district of North Gujarat region. Dairy Planner, 5: 8-10.

Chowdhry N R, Patel J B and Bhakat M. 2008.A study of adoption of milking and healthcare practices of dairy animals under co-operative network of Banas milk union of North Gujarat. Indian Journal of Animal Research, 42 (2): 153-154.

Gupta D C, Suresh A and Mann J S. 2008.Management practices and productivity status of cattle and buffaloes in Rajasthan. Indian Journal of Animal Science, 78 (7): 769-774.

Jadhav S J, Rani D V, Pansuriya D V, Chaudhary J H, Chauhan V D and Pandya S. S. 2014. Feeding practices of dairy animals in periurban areas of Surat district (Gujarat).International Journal Advanced Multidisciplinary Research, 1(3): 1-5.

Jatoliya P, Chandra S J, Meena S M, Lawania P, Bugaliya H L and Kumar D. 2017. Existing management practices of buffaloes owners in Udaipur district of Rajasthan. International Journal of Current Microbiology and Applied Sciences, 6(8): 2103-2108.

Kalyankar S D, Chavan C D, Khedkar C D and Kalyankar S P. 2008. Studies on management practices of buffaloes in different agro-climatic zones of Maharashtra. Indian Journal of Animal Research, 42(3): 157-163.

Kushwaha B P, Kundu S S, Kumar A,Maity S $B$ and Singh S. 2007. Status of Bhadawari breed of buffalo in its breeding tract and its conservation. Indian Journal of Animal Science, 77 (12): 1293-1297.

Malsawmdawngliana $\mathrm{R}$ and Rahman $\mathrm{S}$. 2016.Management practices followed by the dairy farmers of Mizoram, India.Journal of Livestock Science 7:
220-225.

Malik D S and Nagpaul P K. 1999.Studies on milking and calf rearing management practices of Murrah buffalo in its hometract of Haryana. Indian Journal of Animal Production Management, 15 (2): 52- 54.

Manohar D S, Goswami S C and Bias B. 2014. Study on feeding management practices of buffaloes in relationship with selected traits of respondents in Jaipur District of Rajasthan. Indian Journal of Animal Research, 48(2): 150-154.

Meena H R, Ram H,Sahoo A and Rasool T J. 2008. Livestock husbandry scenario at high altitude kumaon Himalaya, Indian Journal of Animal Sciences, 78(8): 882886.

Modi R J and Patel N B. 2010. Breeding practices in dairy animals of rural area under milk shed of north Gujarat. Indian Journal of Field Veterinarians, 5(4):5-6.

Pata B A, Odedra1 M D, Ahlawat A R, Savsani1 H H, Patbandhal T K and Sarma M P. 2018a.Survey on Socio Economic and Milking Patterns of Buffaloes Owners in Junagadh and Porbandar District of Gujarat, India.Int.J.Curr.Microbiol.App.Sci., 7(8): 1203-1212.

Pata B A, Odedra1 M D, Ahlawat A R, Savsani1 $\mathrm{HH}$ and Patbandha1 $\mathrm{T} \mathrm{K}$. 2018b.Survey on Housing and Feeding Practices of Buffaloes Owners in Junagadh and Porbandar District of Gujarat, India.Int.J.Curr.Microbiol.App.Sci., 7(8): 1195-1202.

Patel N B, Patel J B,Prajapti K B and Suthar B N. 2005. Breeding practices in dairy animals of rural area under Patan district of North Gujarat. National seminar on 'Recent advances in conservation of Biodiversity and augmentation of reproduction and 
production in farm animals' held 5-7 March, 2005 at SardarKrushinagarDantiwada Agricultural University, SardarKrushinagar. Pp: 252.

Pawar B K,Nalawade T H and Jagtap D Z. 2006.Adoption of bovine feeding practices and constraints faced by tribal farmers of Pune district.Journal of Maharastra. Agriculture University, 31(3):329-330.

Pundir R K, Sahana G, Navani, N. K, Jain P K, Singh D V,Satish K and Dave A S. 2000. Characterization of Mehsani buffaloes in India. Animal Genetic Resources Information, 28(1): 53-62.

Sabapara G P, Desai P M, Kharadi V B,Saiyed L H and Singh R R. 2010. Housing and feeding management practices of dairy animals in the tribal area of South Gujarat. Indian Journal of Animal Sciences, 80(10): 1022-1027.

Sabapara G P,Fulsoundar A B and Kharadi VB. 2015. Milking and Health Care Management Practices Followed by Dairy Animal Owners in Rural Areas of Surat District.Sch J Agric Vet Sci ;2(2):112-117.

Sreedhar S, Reddy A N, Ramesh Babu P, Sudhakar B V, Kamalakar G and Tejaswi V. 2017. Milking management practices and marketing of milk in Rayalaseema region of Andhra Pradesh. International Journal of Pure And Applied Bio Sciences, 5(6): 524-530.
Singh M, Chauhan A,Chand S and Garg M K. 2007. Studies on housing and health care management practices followed by the dairy owners. Indian Journal of Animal Research, 41 (2): 79-86.

Singh A S, Khajan S and Imtiwati 2013. Adoption of Improved Dairy Husbandry Practices By Dairy Farmers In Hill Region Of Manipur, India. Asian $J$. Dairy \& Food Res., 32 (4): 283-289.

Singh M, Chakravarty R, BhanotraA.and Kumar M. 2015.Dairy animal health and housing management practices followed by tribal dairy farmers of Ranchi, Jharkhand. International Journal of Farm Sciences 5(3): 199206.

SinhaR R K, Dutt T B, Singh R R and Singh M. 2009. Production and reproduction profile of cattle and buffaloes in Bareilly district of Uttar Pradesh. Indian Journal of Animal sciences, 79 (8): 786787.

Swaroop D and Prasad J. 2009.Housing systems of dairy cattle and buffaloes in rural area of trans-yamuna Allahabad district. Indian society of animal production and management, national symposium, pp: 178.

Tiwari H, Kumar S, Singh D V, Rath R and Tyagi K. 2018.Studies on existing milking and health care practices adopted by dairy farmers in Tarai region of Uttarakhand, India.Indian Journal of Animal Research, 52 (3): 454-458.

\section{How to cite this article:}

Avanish Kumar, Vipin Kumar Upadhyay and Vishwa Pratap Singh. 2020. Existing Dairy Husbandry Practices followed by Livestock owners in Farrukhabad District of Uttar Pradesh. Int.J.Curr.Microbiol.App.Sci. 9(02): 1863-1873. doi: https://doi.org/10.20546/ijcmas.2020.902.213 